\title{
FARMERS' WILLINGNESS TO PAY FOR WEATHER FORECAST INFORMATION IN SAVELUGU-NANTON MUNICIPALITY OF THE NORTHERN REGION
}

\author{
Franklin Nantui Mabe, Prince Nketiah, Daniel Darko, Researchers \\ University for Development Studies, Tamale, Ghana \\ E-mail: raxffranklin@gmail.com
}

\begin{abstract}
In the quest for farmers to get maximum output and improve their livelihood within the major constraint of depending on rain-fed agriculture, the issue of having access to weather forecast information is very important. A contingent valuation method was used to elicit the amount farmers are willing to pay for accessing unpriced weather forecast information in the Savelugu-Nanton Municipality of the Northern Region. Farmers were also asked to rank weather forecast variables according to their level of importance. An open ended stated preference approach was employed. The study also used multivariate regression model to identify the factors which significantly affect the amount farmers are willing to pay for weather forecast information. Chance of rain was considered the most important weather forecast information required by farmers. The study found out that farmers on the average are willing to pay an amount of $\mathrm{GH} \phi 41.20$ annually for weather forecast information. The study revealed that age, sex, farm size and on-farm income significantly and positively affect the amount farmers are willing to pay for weather forecast information. Weather forecast information delivery should therefore be a key factor in all agriculture policy discussions in enhancing farm risk management. Government and investors could also increase their revenue base by expanding and providing weather information to farmers for a fee.
\end{abstract}

\section{KEY WORDS}

Weather; Information systems; Farmers; Fee.

Weather information is a public good which farmers all over the world need in making decisions in relation to the management of their farming activities. It helps in the management of on-farm and off-farm risk. Most of the farming activities depend greatly on weather. The role of weather information in farming cannot be underestimated. Predictions of weather information are critical in farming. Several governmental and non-governmental institutions around the world are involved in weather pattern predictions and information delivery. In ancient times, many philosophers have used weather to predict events in the world. Graham et al. (2002) indicated that, «by the end of the renaissance, it had become evidently clear that the speculations of natural philosophers were inaccurate and that greater knowledge was necessary to further the understanding of the atmosphere». Scientific weather forecasting which is more accurate, credible and reliable emerged in the mid nineteenth century. The changing climatic conditions are now closely monitored by scientists all over the world.

There is a strong correlation between climate change and agricultural production. The Intergovernmental Panel on Climate Change (IPCC) has predicted that considering the spate of changes in climatic conditions, rainfed crop production could decrease by $50 \%$ by 2050 (IPCC, 2007). According to International Food Policy Research Institute (IFPRI) (2009), most African countries particularly those in sub-Saharan Africa are the most vulnerable to changes in climatic conditions owing to the fact that agriculture forms a larger share of GDP, export incomes and employment. Therefore, understanding the expected short run and long run changes in the weather variables will go a long way to assist smallholder farmers plan for the framing activities with the aim of lessening the potential effect of the weather.

The availability, accessibility and usability of accurate weather information is critical to farmers especially smallholder farmers. Inaccurate weather information affects particularly smallholder farmers whose livelihood depends mostly on agriculture. All over the world, weather information is regarded a public good with the properties of non-excludability and non-rivalry. Owing to this, governments around the world play a principal role in the provision 
of weather information to the general public. In recent times, the public good property of weather information is fading out since certain people cannot obtain certain critical and vital weather information. In Ghana, weather information comes in the form of quasi-public good with some excludability. This feature makes it possible to deny others from using forecasts information without paying. The institution responsible for weather forecasting in the country is Ghana Meteorological Agency (GMA). Its mandate is to collect data about weather variables, analyse them, and provide services on individual basis to farmers, research institution and other private and public agencies. The agency charges a fee depending on the information being sought for and the use of the information. Majority of smallholder farmers recognizes the availability of weather information as a sole responsibility of government. Hence, they do not realise the need for them to personally seek for weather information since they believe it is a public good. Meanwhile, certain vital weather information require by farmers for specific farming purposes are not made available to the general public. Apart from sketchy information that farmers get on radios and televisions, they do not have the opportunity to access it at their own will for their own specific need.

The essence of weather information cannot be underscored within the prevailing trend of erratic weather patterns. Mabe et al., (2012) estimate the adaptive capacities of rice farmers in the face of climate change in then Savelugu-Nanton Municipality and TolonKumbungu Districts. This study failed to look at whether farmers who have access to weather information are highly adaptive to climate change or not. It is expected that for smallholder farmers to adapt well to climate change, they should have the access to weather information. Many researches on climate change in the study area and Ghana as a whole (Stephens, 1996; Mabe, 2013; Stutley, 2010; Nakuja, 2012 etc) failed to value farmer's willingness to pay for weather information. Considering the vulnerability of farmers in the study area to weather variability; one need to ask whether farmers are willing to pay for weather information or not. If they are willing, at what value and what are the determinants of their willingness to pay?

\section{LITERATURE REVIEW}

The Evolution of weather forecasting. The evolutions of weather prediction over the years have fascinated several scholars and people of elite found within the field of climate and weather related studies. Many countries attribute forecasting of weather changes to ancestral lineage. Weather forecasting can be traced back to the early civilization, where metrological events were used to predict likely future happenings. According to Graham et al. (2002), in the year 650 B.C., Babylonians predicted temporal weather changes based on visual signs of clouds and other such phenomena. The study further revealed that, scientific weather observation stations emerged in 1860's spreading all over the world, thereby providing synoptic weather forecasting.

Use of weather information. Agro-meteorological information supports all aspects of farming and related agricultural activities worldwide. Irrespective of the spate of technological advancement, a greater portion of agricultural production occurs in the natural environment. Therefore, changes in the weather conditions affect agricultural production. Considering the cost of agricultural production, accurate weather information can help farmers take prudent decisions to reduce the wasteful use of agricultural inputs. It can also ensure optimality in the operations of weather-specific activities during production (Predicatori et al. 2008). Forecast that offer accurate information on humidity, drought, temperature and rainfall remains vital in helping farmers to optimally allocate resources. Another point of view as expressed by Craft (2001) indicated that, the most obvious use of weather information is the influence that such information would have on decisions taken in response to expected outcomes. The author also asserted that, weather information can indirectly affect prices of agricultural produce through supply chain.

Farmers use weather forecast information to help them decide when to start production. They use weather forecast information such as prediction of precipitation (amount and pattern), temperature, wind speed and direction, solar radiations, humidity and 
evapotranspiration. The predicted weather information on these variables is either metrological or climatological. Metrological forecast is the type of forecast that covers the time period from hours to less than fifteen days whilst climatological covers a time period from fifteen days to infinity. All these information can be used for short run or long run planning purposes in farming.

Demand for weather information varies among different actors in the agriculture value chain. Weather forecast provided via mobile phone technology is highly sought by smallholder farmers in Kenya (Pshenichnaya, 2012). Meanwhile, the demand for weather information by farmers depends on the attributes of the particular weather information. Stone and Meinke (2006) looked at weather information as a product for farmers in two distinct forms; tactical (short-term) and strategical (long-term) based on the time range to which key management decisions are influenced by weather information. Sonka et al. (1987) indicated that, to ensure efficiency in the farming process, key areas of production where tactical changes can be made should be identified in order to prevent loses in predicted belowaverage rainfalls and take advantage of above-average scenarios.

Weather information as a public good. Non-market valuation methods have been used by many researchers to value many public or quasi-public goods. Weiher (2002) looked at forecast information as a public good which is "non-rivalry» and potentially "nonexcludable». A public good is a good which is openly available equally to everybody and one person's usage of the good causes no change to its value. In a sharp contrast, Lazo (2006) looked at weather information as quasi-public good. Quasi-public goods are "excludable» and «rival» in nature. This classification implies that some weather forecasts come with the possibility that other people cannot access them without paying and some also come with the possibility that persons previewed to the information may have competitive advantage from knowing what someone else does not.

Valuation of weather information. Contingent valuation method (CVM) has been used by many researchers. It involves the use of field survey to elicit information on the value people assign to non-market goods. CVM is an economic valuation which refers to the assignment of monetary values to the changes in environmental services and functions and to stocks of environmental assets» (Pearce et al., 2000). Davis (1963) is credited for the practically usage of CVM to estimate the value that hunters and tourists place on marine wood. Weather information comes as a public good, in the sense that, it has no existing data on market prices and quantities.

Many researchers around the globe have dealt with valuation of weather predictions and their resultant economic effect. Rollins and Shaykewich (2003) estimated the benefits generated from weather information usage by commercial users. Williamson et al. (2002) examined how enhanced forecasts made by satellite data have led to several social and economic benefits. In addition, Davidson et al. (2012) demonstrated the economic value of environmental prediction of weather information to selected enterprises involved in the production, transmission and distribution of energy. On the other hand, several studies have also looked at value of weather information with respect to agriculture. Predicatori et al. (2008) determine the real value of weather forecast information in addition to cost benefits analysis, Spicka and Hnilica (2013) gave overview on data sources and evaluation of weather derivatives.

\section{METHODOLOGY}

Empirical determination of the level of importance farmers attached to weather forecast variables. Inadequate weather information and its adverse effects on farming can be effectively reduced through the provision of adequate weather information to farmers. Adequacy of weather information also depends on the content and the importance of the content to be delivered to farmers through which they can base their farming decisions. In this study, farmers were asked to indicate the level of importance they attach to six weather forecast variables (WFV). These WFV are chance of rain, amount of rain, cloudiness of weather, low temperature, high temperature and windiness of weather. Table 1 shows how 
farmers attached importance to weather forecast variables. For instance, if a farmer attributes extremely importance to chance of rain, then a score value of 5 is recorded against chance of rain. A least score value thus 1 indicated against a weather forecast variable show that it is not important at all to the farmer.

Table 1 - Score levels of importance of weather forecast variables

\begin{tabular}{|c|c|c|c|c|c|}
\hline WFV/Level of importance & $\begin{array}{c}\text { Not at all } \\
\text { important }\end{array}$ & $\begin{array}{c}\text { A little } \\
\text { important }\end{array}$ & $\begin{array}{c}\text { Somewhat } \\
\text { important }\end{array}$ & $\begin{array}{c}\text { Moderately } \\
\text { important }\end{array}$ & $\begin{array}{c}\text { Extremely } \\
\text { important }\end{array}$ \\
\hline Chance of rain & 1 & 2 & 3 & 4 & 5 \\
\hline Amount of rain & 1 & 2 & 3 & 4 & 5 \\
\hline Cloudiness of weather & 1 & 2 & 3 & 4 & 5 \\
\hline Low temperature & 1 & 2 & 3 & 4 & 5 \\
\hline High temperature & 1 & 2 & 3 & 4 & 5 \\
\hline Windiness of the weather & 1 & 2 & 3 & 4 & 5 \\
\hline
\end{tabular}

In determining the mean score value for the rankings the level of importance of WFV, the formular given below is used:

$$
\text { Mean score for Nth WFV }=\frac{\text { Total score for } j \text { th } W F V}{\text { Number of respondent }}
$$

where WFV = Weather forecast variable.

The WFV with the highest mean score is the one which is extremely important and most preferred by farmers. The higher the mean score value, the more important and preference farmers attached to the phenomena of weather forecast variable concerned.

Conceptual framework of contingent valuation method. Weather and climate forecast information can only be said to be having value if they results in improved decision making for the betterment of human life. Weather information is supposed to be used for societal well-being. Farmers are one of the social and economic groups of people who require weather information in their agricultural activities. This implies when appropriate weather forecast information are made accessible to farmers for use, they would be able to improve upon agricultural production through prudent decision on all stages of the production process. Weather forecast information has a value. The method which is widely used to elicit the value of a non-market good is contingent valuation method (CVM). CVM involves direct questioning of respondents to state their willingness to pay (WTP) for increase in quantity or quality of a good or willing to accept (WTA) a compensation for the reduction in quantity or loss in value of a good. This technique of valuing the environment allows for the identification of preferred plan for weather information from the demand perspective. Stated preference approach and revealed preference approach are the two CVM which can be used to determine the value of an environmental good. In this paper, the researchers used a stated preference technique that allows the respondent to have enough flexibility to state willingness to pay for both used and unused resources.

Theoretical framework. The theoretical underpinning of CVM is the theory of consumer behavior. Consumers are rational and aim at maximizing utility from any bundle of goods. It is imperative to note that utility function and attributes of the commodity under question must be critically considered in the estimation of WTP. An individual seeks to maximize utility of a good (in this case weather forecast information) subject to a given constraint. Meanwhile, Khuc (2013) used indirect utility function to derive WTP for drinking water in Vietnam. In equation (2) below, a farmer aims at maximizing utility derive from using weather forecast information in agricultural production process given the quantity of the forecast information and income.

$$
U=u *\left(q_{1}, q_{2}, \ldots, q_{n}\right)
$$


Meanwhile, utility function is a summary of one's preference and taste for a commodity with regard to purchases which affect the expenditure. Khuc (2013) indicated that an individual rather seeks to minimize his or her expenditures in order to attain a certain level of utility $u^{*}$. Therefore, the expenditure function for a farmer when the quantity $\left(q_{0}\right)$ of weather forecast information is delivered by government without charging a fee is given as:

$$
e=e\left(P, q_{0}, u^{*}\right)
$$

For a farmer to willingly source for specific quantity and quality $\left(q_{1}\right)$ of weather forecast information to meet his or her own need in production activities, that farmer is prepared to increase his or her expenditure. The WTP is then derived as the difference in the farmer's expenditures thus:

$$
\begin{gathered}
W T P=e\left(P, q_{0}, u^{*}\right)-e\left(P, q_{1}, u^{*}\right) \\
\text { where } q_{1}>q_{0}
\end{gathered}
$$

Empirical model. In this study a farmer is asked to state how much he or she is willing to spend in order to obtain or access specific weather forecast information per year. The average WTP is calculated using the formula below:

$$
\text { Average }=\frac{\sum_{i=1}^{n} W T P_{i}}{n}
$$

where, ' $n$ ' is number of respondents.

Meanwhile, the stated WTP amount by each farmer is determined by certain socioeconomic factors. In describing decision of farmers to pay for the provision of weather information, this study based on the principal idea that people have preferences for public goods and these interests are not known (Sumukwo et al., 2012). These preferences can therefore be stated in money equivalence in making bids for willingness to pay. Farmers have varying willingness to pay amounts for weather information and hence, there is the need to determine determinants of willingness to pay bids. Acquah (2011) identified age, household size and years of farming experience as determinants of willingness to pay for climate change mitigation. Sumukwo et al. (2012) in the analysis of willingness to pay for improved household solid waste management considered sex, age, education, income and total disposal methods available to households. In a study conducted by Kwadzo et al. (2013) on food crop farmers' willingness to participate in market-based crop insurance scheme in Ghana used, they used farmer characteristics such as age, educational level, household income, years of farming (experience), farm size, land tenure, enterprise diversification, total asset and total debt as the independent variables. Danso-Abbeam et al. (2013), regressed age of farmer, age squared of the farmer, gender, size, number of years in farming cocoa, farmer-based organization, farm size, ownership of farm land, average age of the cocoa farm, average age squared of the cocoa farm, income from cocoa farm and whether farmers are aware of cocoa insurance policy on the willing to pay bid for cocoa insurance in Ghana. This study considers age, sex, membership of an FBO, access to extension services, farm size, on-farm income level, off-farm income, educational level and years of farming experience as the explanatory variables. bellow.

Empirically, the WTP amount is regressed on the socioeconomic factors as stated

$$
\begin{aligned}
& W T P_{i}=\beta_{0}+\beta_{1} \operatorname{Sex}_{i}+\beta_{2} E d u_{i}+\beta_{3} F_{B O}+\beta_{4} E_{i}+\beta_{5} \ln \text { Age }_{i}+\beta_{6} \ln F_{m} S_{i}+ \\
& \beta_{7} \ln \text { FmExp }_{i}+\beta_{8} \text { FmInc }_{i}+\beta_{9} \ln \text { OffFmInc }_{i}+\beta_{10} \text { MSta }_{i}+\varepsilon_{i}
\end{aligned}
$$


Different functional forms such as; linear, log-linear, linear-log and log-log regressions were used to estimate the parameters and the best-fit function (linear-log) was adopted for this study.

Table 2 - Summary of explanatory variables use in the regression model

\begin{tabular}{|c|c|c|c|c|}
\hline $\begin{array}{l}\text { Explanatory } \\
\text { variable }\end{array}$ & Description & Measurement & $\begin{array}{c}\text { Slope } \\
\text { coefficient }\end{array}$ & $\begin{array}{c}\text { A priori } \\
\text { expectations }\end{array}$ \\
\hline Sex & Sex of household head & 1 if male, 0 if female & $\beta_{1}$ & + \\
\hline Edu & $\begin{array}{c}\text { Educational level of household } \\
\text { head }\end{array}$ & $\begin{array}{c}1 \text { if access, } 0 \\
\text { otherwise }\end{array}$ & $\beta_{2}$ & + \\
\hline$F B O$ & Member of an FBO & $\begin{array}{l}1 \text { if member, } 0 \\
\text { otherwise }\end{array}$ & $\beta_{3}$ & + \\
\hline Ext & $\begin{array}{c}\text { At least } 3 \text { visits by extension } \\
\text { officers in a year }\end{array}$ & 1 if yes, 0 otherwise & $\beta_{4}$ & + \\
\hline Age & Age of the household head & years & $\beta_{5}$ & + \\
\hline FmS & Farm size & Acres & $\beta_{6}$ & + \\
\hline FmExp & Farming experience & $\begin{array}{c}\text { Number of years of } \\
\text { farming }\end{array}$ & $\beta_{7}$ & - \\
\hline$F m / n$ & On-farm income & Ghana cedis $(\mathrm{GH} \phi)$ & $\beta_{8}$ & + \\
\hline OffFmInc & Off-farm income & Ghana cedis $(\mathrm{GH} \phi)$ & $\beta_{9}$ & - \\
\hline MStat & Marital status & $\begin{array}{l}1 \text { if married, } 0 \\
\text { otherwise }\end{array}$ & $\beta_{10}$ & $+/-$ \\
\hline
\end{tabular}

Sampling method and sample size. The study used a multi-stage sampling technique. The researchers purposively selected Northern region for the study. This was as a result of the fact that it is the largest region with largest number of smallholder farmers in Ghana. After the selection of the region, all the 26 districts in the region were given an equal chance of selection through simple random sampling. The communities were randomly selected. Also, ten respondents each were randomly interviewed in ten communities (Bunglung, Botingli, Damdu, Challam, Yong, Tunayili, Dipeli, Diare, Gushei, and Adayili) within Savelugu-Nanton Municipality. Therefore, a total number of 100 farmers were diligently interviewed. Many economists have stated varying biases on CVM including hypothetical bias, strategic bias, information bias and embedding effect (Spash, 2008). Meanwhile, carefully selected steps were taken to help mitigate the effects of these prospective limitations on the outcome of this study. A hypothetical situation was created and the respondents were given clear explanations and feedback taken to ascertain level of understanding before the interview was conducted. The respondents were asked to state their willingness to pay for accessing scientific weather forecast information.

Study area. Savelugu-Nanton Municipality is one of the districts in the northern region of Ghana. The Municipal capital is Savelugu and it is about $25 \mathrm{~km}$ from Tamale. The municipal shares boundaries with Tolon and Kumbungu Districts to the west, West Mamprusi and Mamprugu-Moaduri Districts to the north, Tamale Metropolis to the south and Yendi Municipal to the South-East. The municipality has a population size of about 112,797 with annual growth rate of $3 \%$ and an average household size of 8.7 persons per household. Peasant level agriculture is predominant as it engages about $97 \%$ of the labour force. Some major crops cultivated within this municipality include maize, groundnut, soyabeans and rice. Temperatures in this municipality are usually high, averaging $34^{\circ} \mathrm{c}$, with maximum $42^{\circ} \mathrm{c}$ and minimum $16^{\circ} c$.

\section{RESULTS AND DISCUSSIONS}

Demographic characteristics of respondents. The total number of respondents interviewed in Savelugu-Nanton Municipality was 100 . Out of this number, $85 \%$ of them were male and $15 \%$ females. The average age of respondents was 40 years. Ages within the range of $41-50$ were the majority representing $26 \%$ of the total respondents. They were 
followed closely by $31-40$ years with a percentage of $24 \%$. Range of ages of $51-60,61-$ 70 and $21-30$ recorded percentage values of $18 \%, 14 \%$ and $13 \%$ respectively. The age range $21-30$ emerged as the least of the respondents and this shows how the young adults and the youth are less engaged in farming. Most of the energetic youth travel out of the communities in search of greener pastures leaving the farming business to the aging group.

Sixty percent $(60 \%)$ of the respondents had no formal education and $40 \%$ had some form of education. Out of the $40 \%$ who are educated, $37.5 \%$ had primary education, $15 \%$ had middle school education, $17.5 \%$ had junior high school (JHS) education, $27.5 \%$ had senior high school (SHS) education and $2.5 \%$ had tertiary education. It is expected that farmers who are able to read and write on farming processes and keep clear data on their activities on the farm would enjoy higher agriculture productivity. Farmers with farm sizes within the range of $6-10$ acres led the population with $48 \%$, followed by $1-5$ with $31 \%$ and $11-15,16-20$, and $21-25$ acres representing 16\%, 4\% and 1\% respectively. On-farm income received by farmers in the 2013 farming season ranges from $\mathrm{GH} \phi 139.00$ to $\mathrm{GH} \phi 19,400.00$. Majority constituting $58 \%$ of the respondents interviewed earned an annual on-farm income between $\mathrm{GH} \phi 1.00$ to $\mathrm{GH} \phi 2,000.00$. The least number of farmers $(2 \%)$ received an annual on-farm income of $\mathrm{GH} \phi 8,001.00-\mathrm{GH} \phi 10,000.00$ whilst $26 \%, 8 \%, 4 \%$ and $3 \%$ of the sampled farmers earned an annual on- farm income of $\mathrm{GH} \phi 2,001.00$ $\mathrm{GH} \phi 4,000.00, \quad \mathrm{GH} \phi 4,001.00-\mathrm{GH} \phi 6,000.00, \mathrm{GH} \phi 6,001.00-\mathrm{GH} \phi 8,000.00$ and above $\mathrm{GH} \phi 10,000.00$ respectively.

Ranking of weather forecast variables according to level of importance. The use of weather forecast variables varies from farmer to farmer. The weather forecast variables do not have the same level of importance. Farmers ranked their preference for weather forecast variables by revealing the importance to which the given weather forecast phenomena would contributes to their production activities. The mean score values and the rankings for the weather forecast variable are indicated in table 3 below. In all, chance of rain was ranked first indicating that it is the most importance weather indicator they need in their farming activities. The mean score value of 4.75 was recorded for the chance of rain. This suggest that farmers prefer to be updated on chance of rain more frequently as it helps them to plan on when to plant or more generally on when to start certain farming activities. The second most important weather forecast variable that farmers need information on is the intensity of rain. The rainfall intensity affects erosivity of soil as well as crop yield. The ability of farmers to till the land either manually or mechanically depends heavy on the intensity of rainfall received. When the rainfall intensity is very low, farmers will not be able to plant crop. From table 3 below, it is clear that the humidity of the weather is not so much important to farmers in the study area. It is the weather forecast phenomenon which scored the lowest level of importance thus 3.98. According to the level of importance, cloudiness of weather, the degree of hotness or coldness of the weather and windiness of weather had the mean score values of $4.31,4.21$ and 3.99 respectively.

Table 3 - Means score ranks of weather forecast phenomena

\begin{tabular}{|c|c|c|}
\hline Weather forecast variables & Mean score $=\frac{\text { Total score for } j \text { th } W F V}{\text { Number of respondent }}$ & \multirow{2}{*}{ Rankings } \\
\hline Chance of rain & $475 / 100=4.75$ & 1 st \\
\hline Intensity of rain & $459 / 100=4.59$ & 2 nd \\
\hline Cloudiness & $431 / 100=4.31$ & 3 rd \\
\hline High temperature & $421 / 100=4.21$ & 4 th \\
\hline Low temperature & $421 / 100=4.21$ & 4 th \\
\hline Wind intensity & $399 / 100=3.99$ & 6 th \\
\hline Humidity & $398 / 100=3.98$ & 7 th \\
\hline
\end{tabular}

Source: Field survey (2014)

Willingness to pay for scientific weather forecast information. A hypothetical market was presented to respondents for the purpose of contingent valuation. The scenario was carved to include statements such as: «a firm is ready to deliver weather information to 
respondents through mobile calls». They were also informed that the information would be conveyed in their own local languages and they would have the chance to interact and ask what ever information they want about weather information. Lastly, we told them the information would be location specific and not general. When respondents were presented with this market scenario and had clearly understood of it, they all expressed that they would want to have such service and they are ready to pay. They were of the view that access to weather information via mobile phones would help them very much in the work on farm. Respondents were willing to pay money or give out some produce to the service provider at the end of the farming season. They were willing to give either a bag or half a bag of the following; maize, groundnut, aleefu, rice, soybeans and Bambara beans. Some also were willing to give tubers of yam, whilst others were willing to pay physical money. The produce quantities proposed by farmers were converted to monetary values using the prevailing 2013 market prices.

When the produce were converted to cash the lowest WTP amount was $\mathrm{GH} \phi 3.00$ and the highest was $\mathrm{GH} \phi 140.00$. The amount with highest frequency was $\mathrm{GH} \phi 40.00$ with 28 respondents, followed by $\mathrm{GH} \phi 56.00$ and $\mathrm{GH} \phi 20.00$ having 10 and 9 respondents respectively. Also, $49 \%$ of the respondents offered amounts within the range of $\mathrm{GH} \phi 10.00-$ $\mathrm{GH} \phi 50.00,26 \%$ also offered amounts between $\mathrm{GH} \phi 50.00-\mathrm{GH} \phi 100.00$ and $20 \%$ of the respondents were prepared to pay $\mathrm{GH} \phi 0.00-\mathrm{GH} \phi 10.00$. Lastly, $5 \%$ of the respondents were willing to give above $\mathrm{GH} \phi 100.00$. Farmers on the average were willing to pay an amount of $\mathrm{GH} \phi 41.20$ per year for weather information, with the overall data spread of $\mathrm{GH} \phi 29.56$ around the mean. The summary statistics of the WTP amounts are shown in table 4 below whilst the frequency of the WTP bids are shown in figure 1.

Table 4 - Descriptive statistics of WTP amounts

\begin{tabular}{|c|c|}
\hline Descriptive statistics indicators & Values \\
\hline Mean & 41.20 \\
\hline Median & 40.00 \\
\hline Coefficient of variation & 0.717 \\
\hline Variance & 873.597 \\
\hline Standard deviation & 29.557 \\
\hline Standard error of the mean & 2.971 \\
\hline Skewness & 1.065 \\
\hline Kurtosis & 4.358 \\
\hline
\end{tabular}

Source: Field survey (2014)

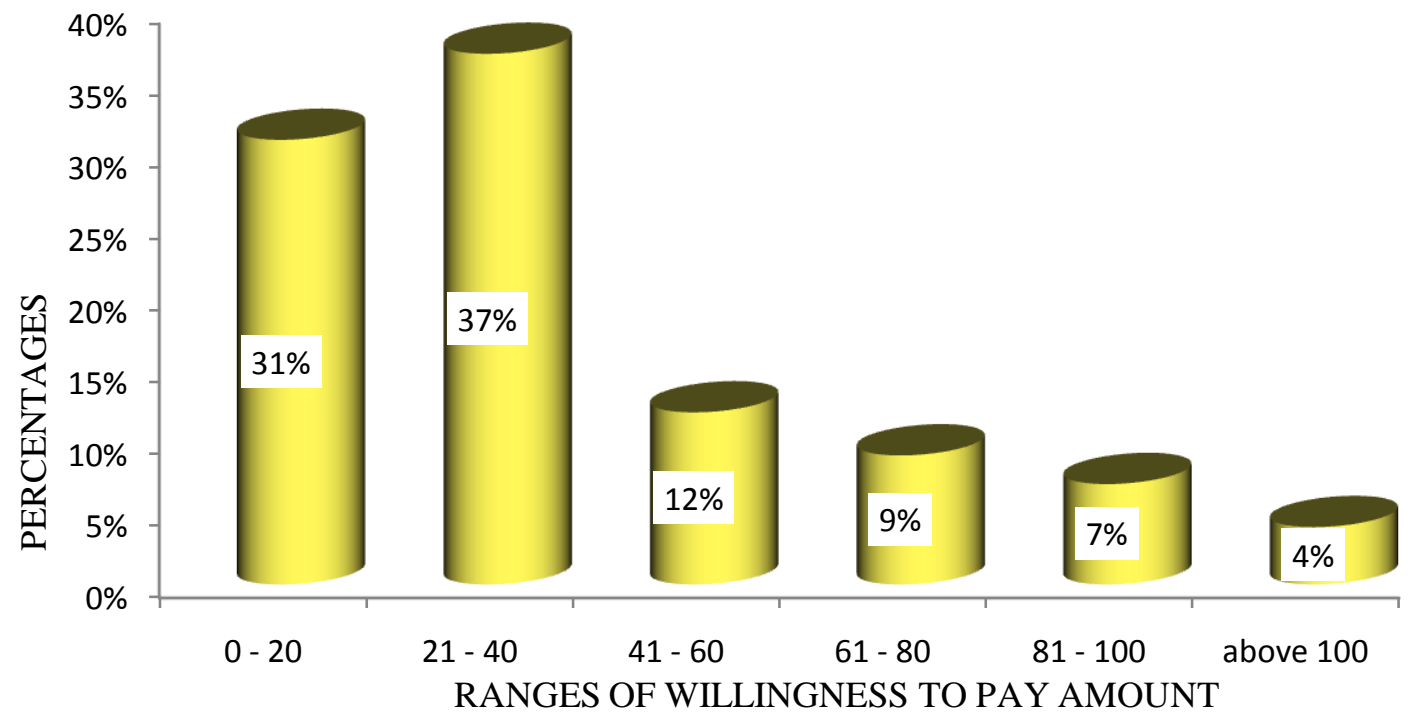

Figure 1 - Bar chart showing frequency of WTP amounts (Source: Field survey, 2014) 
Determinants of Willingness to Pay. Socio-economic factors influencing farmers' willingness to pay bids for weather information was analyzed using Ordinary Least Square estimator. Table 5 shows the regression results that explains the determinants of WTP for weather forecast variables. The multivariate regression analysis gave a goodness of fit value of 0.81 . This indicates that $81 \%$ of the variations in the WTP amount is explained vividly by the explanatory variables (socio-economic factors).

Table 5 - Linear-log regression results explaining the determinants of WTP amounts

\begin{tabular}{cccc} 
Explanatory variables & Estimates & t - value & Significance \\
\hline Sex & 19.8569 & 2.51 & $0.019^{* *}$ \\
Edu & 0.9292 & 0.14 & 0.887 \\
FBO & 2.8609 & 0.44 & 0.664 \\
Ext & 9.8688 & 1.65 & 0.112 \\
Age & 35.7527 & 1.98 & $0.058^{*}$ \\
FmS & 24.3134 & 3.45 & $0.002^{* * *}$ \\
FmExp & -6.1093 & 0.393 & $0.000^{* * *}$ \\
FmIn & 17.2436 & 4.54 & 0.512 \\
CffFmInc & 2.2803 & 0.67 & 0.000 \\
\hline$* * * * *$ represtant & -278.9208 & -4.34 & 0 \\
\end{tabular}

Source: Field survey (2014)

As expected, the on-farm income is significant at $10 \%$ and has positive effect on willingness to pay bids. This relationship has a theoretical basis since contingent valuation depends primarily on the amounts individuals are willing to give for weather information. The strong significance of (1\%) of on-farm income on WTP amounts has a direct influence on the demand for weather information and hence the main determinant of willingness to pay amounts. The coefficient value of 17.24 implies that if on-farm income increases by $1 \%$, the WTP amount will increase by GH $\not 17.24$. Sex of respondents on the other hand is positive and significant $(5 \%)$ showing that males have higher WTP amount than females. This is because men have more access and control over land and hence had larger farms and larger farm incomes as compared to the women engaged in farming. Age is significant at $10 \%$ and has a positive effect on the WTP amount. This is in conformity to the a priori expectation. The positive effect is attributed to the fact that older people have greater access and control over land as compared to younger people in the Savelugu-Nanton Municipality and therefore have higher output levels that translate into their higher willingness to pay bids. Therefore, the WTP amount will increase by $\mathrm{GH} \phi 35.75$ for a $1 \%$ increase in the years of the farmer.

Farm size is also significant (1\%) and positive with respect to the farmers bids on willingness to pay amounts. If the farm size increases by $1 \%$, the WTP amount will increase by $\mathrm{GH} \phi 24.31$. Farmers with larger farm sizes have the potential of receiving high incomes from the sale of their farm produce and hence were willing to pay relatively higher amounts for weather information especially those with high on-farm income as well as large farm sizes. In a nut shell, the determinants of WTP for weather forecast information are age, sex, farm size and on-farm income. It was surprising to see that access to education has no effect on WTP amounts.

\section{CONCLUSION AND POLICY RECOMMENDATIONS}

In the quest for farmers to get maximum output and improve their livelihood within the major constraint of depending on rain-fed agriculture, the issue of having access to weather forecast information is very important. It is in this light that $100 \%$ of respondents expressed their willingness to pay for weather information. With an average willingness to pay amount of $\mathrm{GH} \phi 41.20$ per year, weather information as an economic commodity is consistent with economic theory looking at it from the demand perspective of farmers. Demand for weather information rises with increasing income of farmers. Also 'income' as a variable in the 
regression explains well the relationship it has with WTP bids, hence the economic valuation of farmers' preference for weather information is consistent with economic theory. The consistency in the influence that, output of farmers positively affects willingness to pay bids showed once again as farm size, age and sex were also significant. This is evident as larger farms, higher ages and men had higher WTP amounts respectively, according to the regression results.

There is an urgent need for metrological report that is easily accessible and understandable to farmers. Weather information delivery should be a key factor in all agriculture policy discussions in enhancing farm risk management. Government and investors could also increase their revenue base by expanding and diversifying technology in the delivery of weather information which is specific on the weather phenomenon and location to farmers.

\section{REFERENCES}

1. Acquah, D. H. (2011) «Farmers perception and adaptation to climate change: A willingness to pay analysis». Journal of Sustainable Development in Africa. Volume 13, No.5, 2011.

2. Craft, E. D. (2001) «Economic History of Weather Forecasting». EH.Net Encyclopedia, edited by Robert Whaples. October 6, 2001.

3. URL http://eh.net/encyclopedia/article/craft.weather.forcasting.history

4. Danso-Abbeam, G., Addai, K. N. and Ehiakpor, D. (2013). Willingness to Pay for Farm Insurance by Smallholder Cocoa Farmers in Ghana, Journal of Social Science for Policy Implications, Vol. 2, No. 1, pp. 163-183 ISSN: 2334-2900.

5. Davidson, M., Gurtuna, O., Masse, C., and Mills, B. (2012). «Factors affecting the value of environmental predictions to the energy sector». Informatics for sustainable energy development and environmental management. Springeropenjournal.

6. Davis, R. K. (1963). The value of Outdoor Recreation: An Economic Study of the Maine Woods. Dissertation, Harvard University.

7. Graham, S., Pakinson C., and Chain M. (2002). «Weather forecast through the ages». EOS project science, NASA.

8. International Food and Policy Institute (IFPRI) (2009). Climate change: Impact on agriculture and costs of adaptation. Washington, DC.

9. IPCC, (2007) Summary of policy makers. Climate change 2007. Impact, adaptation and vulnerability: fourth assessment report. Intergovernmental Panel on Climate Change, Geneva.

10. Khuc, V. Q. (2013). Household's Willingness-To-Pay Estimation for Safe Drinking Water: A Case Study in Vietnam. A Thesis Submitted to Department of Agricultural and Resource Economics, Colorado State University in Partial Fulfilment of the Requirements for the Degree of Master of Science.

11. Kwadzo, G. T-M., Kuwornu, J. K. M. and Amadu, I. S. B. (2013). Food Crop Farmers' Willingness to Participate in Market-Based Crop Insurance Scheme: Evidence from

12. Ghana, Research in Applied Economics, Macrothink Institute, ISSN 1948-5433, 2013, Vol. 5, No. 1

13. Lazo, J. (2006) «Thinking about use and value of weather forecasts». Societal Impacts Program - NCAR NAT SERA Workshop - Boulder, CO.

14. Spicka, J. and Hnilica, J. (2013). "A Methodical Approach to Design and Valuation of Weather Derivatives in Agriculture». Advances in Meteorology 2013, 1-8

15. Rollins, K. S. and Shaykewich, J (2003). "Using willingness-to-pay to assess the economic value of weather forecasts for multiple commercial sectors». Meteorological Applications, 10, pp 31-38. doi:10.1017/S1350482703005048.

16. Mabe, F. N., Sarpong, D. B. and Osei-Asare, Y. (2013).Empirical Evidence of Climate Change: Effects on Rice Production in the Northern Region of Ghana, British Journal of Economics, Management \& Trade, 4(4): 551-562, 2014, SCIENCEDOMAIN international www.sciencedomain.org 
17. Mabe, F. N., Sarpong, D. B. and Osei-Asare, Y. (2012). Adaptive Capacities of Farmers to

18. Climate Change Adaptation Strategies and their Effects on Rice Production in the Northern

19. Region of Ghana. Russian Journal of Agricultural and Socio-Economic Sciences, Vol. 1, No. 11,9-17.

20. Nakuja, T., Sarpong, D. B., Kuwornu, J. K. M. and Ashante F. A. (2012). Water storage for dry season vegetable farming as an adaptation to climate change in the upper east region of Ghana. African Journal of Agricultural Research, Vol. 7(2), pp. 298-306.

21. Pearce, D. W. and Seccombe-Hett, T. (2000). «Economic valuation and environmental decision making in Europe». Environmental science and technology/ vol. 36, No 8.

22. Predicatori, F., Giacomazzi, F., Frontero, P., and Bellodi, M., (2008) «Agriculture and climate change: an evaluation of the willingness to pay for improved weather forecast». Final FORALPS Conference on Contributions for a wise management of water resources from meteorology and climatology, Trento Italy.

23. Pshenichnaya, N., (2012) «Tigo and technoserve pilot, Tigo Kilimo service, first lessons learnt». mAgri Blog. www.gsma.com/mobilefordevelopment/2012.

24. Rollins, K., and Shaykewich J., (2003) «Using willingness-to-pay to assess the economic value of weather forecasts for multiple commercial sectors». Meteorol. Appl. 10, 31-38.

25. Sonka, S. T., Mjelde, J. W., Lamb, P. J., Hollinger, S. E. and Dixon, B. L. (1987) «Valuing climate forecast information». J. Clim. Appl. Met. 26: 1080 -1091.

26. Stone, R. C. and Meinke, H. (2006). «Weather, climate, and farmers: an overview». Meteorol. Appl. (Supplement), 7-20.

27. Stephens, C. S. (1996). Some Empirical Evidence of Global Warming in Ghanall, Ghana Journal of Science, Volume 31-36, CSIR, Accra

28. Stutley, C. (2010). Innovation Insurance Product for the Adaptation to Climate Change (IIPACC) Project Ghana, Crop Insurance Feasibility Study 2010

29. Sumukwo, J., Kiptui, M. and Cheserek, G. J. (2012) «Economic Valuation of Improved Solid Waste Management in Eldoret Municipality». Journal of Emerging Trends in Economics and Management Sciences (JETEMS) 3(6): 962-970.

30. Spash C. L., (2008) «The contingent valuation method: Retrospect and prospect. Socioeconomic and the environment in discussion». CSIRO working paper series 2008-04.

31. Weiher, Rodney., (2002) «Economic Value of Current and Improved Weather Forecasts in the U.S. Household Sector».

32. Williamson, R. A., Hertzfeld, H. R. and Cordes, J., (2002). "The socio-economic value of improved weather and climate predictions». Final report: Space policy. http://www.meteo.gov.gh/website/index.php?option=com_content\&view=article\&id=48\&lt emid=76 (Date accessed 31/5/2014). 